\title{
Nanocomposite carbon-bearing sorption material
}

\author{
Sapronova Zhanna Anuarovna \\ Department of industrial ecology \\ Belgorod State Technological University named after V.G. \\ Shoukhov \\ BSTU named after V.G. Shoukhov \\ Russia, Belgorod \\ 308012, Kostukov St., 46 \\ sapronova.2016@yandex.ru
}

\author{
Sverguzova Svetlana Vasilievna \\ Department of industrial ecology \\ Belgorod State Technological University named after V.G. \\ Shoukhov \\ BSTU named after V.G. Shoukhov \\ Russia, Belgorod \\ 308012, Kostukov St., 46
}

\author{
Fomina Ekaterina Viktorovna \\ Department of industrial ecology \\ Belgorod State Technological University named after V.G. Shoukhov \\ BSTU named after V.G. Shoukhov \\ Russia, Belgorod \\ 308012, Kostukov St., 46 \\ fomina.katerina@mail.ru
}

\begin{abstract}
While studying, a new nanocomposite carbon-bearing sorbent (TMCO) has been obtained as a result of thermal modification of sugar industry waste carbonatation sludge. TMCO is a combination of carbonate basis covered by coal nanoparticles. The nanostructured layer from the amorphous carbon is penetrated by a lot of voids and canals, 50 nanometers or less in size, which are active adsorption centers. Experimental studies of wastewater sorption purification with copper and nickel ions, sodium lauryl sulfate, dairy milk processing industry components, oil products, dyes have been conducted. Practical significance of the new sorbent has been confirmed by tests on the factory floor of different enterprises. A complex mechanism of TMCO adsorption action with high wastewater purification has been established that allows recommending the nanocomposite as an effective sorbent to treat wastewater of different chemical compositions.
\end{abstract}

Key words - nanocomposite, carbon, sorbent, adsorption, wastewater, sugar industry waste, ecology

\section{INTRODUCTION}

One of the most effective and simple methods to treat multicomponent wastewater is sorption purification [1].

Adsorption allows removing a large amount of organic and inorganic contaminants from aquatic environment and obtaining a high purity grade of water.

Industrial sorbents based on activated carbons are produced from different types of organic materials - coal, wood and its waste, materials of animal origin, etc. [2-4]. A growing demand for inexpensive sorption materials capable of meeting the requirements specifications stimulates the development of new ways to obtain sorbents [5]. The most efficient in eco-economic trend of research is the development of new inexpensive effective sorbents based on industrial waste that allows decreasing anthropogenic load on the environment in many directions [6-12].

High-effective sorbents are materials obtained on the base of carbon. Recently the sorbents containing nanoparticles have attracted special attention.

The research results reveal that carbon nanomaterials possess much higher sorption capacity than usual activated carbons [13].

In the last decades, carbon nanomaterials have been widely used for heavy metal removal [13, 14]. However, such materials as graphene, nanotubes are synthesized in specific technological conditions; in this respect, their production is very expensive. On the other hand, there is a lot of industrial waste which after being processed can acquire nanostructure that allows applying it as effective sorbents for wastewater treatment.

Except carbon-bearing sorbents, water treatment applies nanosorbents produced from inorganic materials such as metal oxides based on calcium carbonate, nanocomposite polymeric silicates possessing high purification efficiency $[13,15]$.

The compromise between effectiveness and labourintensity of the production can be reached through applying nanocomposite carbon sorbent based on industrial waste.

Large-tonnage waste of sugar industry - carbonatation sludge - contains a large number of finely dispersed particles $\mathrm{CaCO}_{3}$ as well as organic substances that is a good base for creating sorption materials [16-18]

At present approximately $20 \%$ of annual 2.5 million tons of sludge are used for agricultural purposes in Russia. The rest amount is piled up in dumps and some part of it is washed away by water into rivers polluting them [19-21]. 
Taking into account the amount of processed beetroot (there are a lot of sugar mill and refinery plants in Lipetsk, Voronezh, Belgorod, Bryansk and Kursk Oblasts, Krasnodar and Stavropol Krays and other regions), it is possible to state that wastes of sugar beet production are one of the most largetonnage wastes requiring recovery.

\section{MATERIALS AND METHODS}

In experiments, the carbonatation sludge selected at Dmitrotaranovsky sugar mill and refinery plant in Belgorod Oblast has been analyzed. The starting material contains 75$80 \% \mathrm{CaCO}_{3}$ and 20-25\% organic and mineral sugars including nitrogenous and nitrogen free organic compounds (proteins, pectines, calcium salts of organic acids, saponin, mineral substances, etc.). Moreover, the starting sample contains approximately $25 \%$ water, approximately $2 \%$ sugar, $0.2 \%$ nitrogen, $0.15-0.5 \% \mathrm{P}_{2} \mathrm{O}_{5}$ and $0.3-0.5 \% \mathrm{~K}_{2} \mathrm{O}$, the rest is sodium, boron, cobalt and other microelements[19-21]. Most particles of the sludge range from 2 to 40 micrometers in size.

The thermal treatment of the waste test samples has been carried out in the muffle furnace LOIP LF-7/13 in the presence of oxygen.

To determine the concentration of contaminants in standard test solutions and wastewaters, the following conventional methods have been used: integral pollution index - chemical oxygen demand (COD); photocolometric determination $\left(\mathrm{Ca}^{2+}\right.$ and $\mathrm{Mg}^{2+}$ ions); apparatus KFK-3 produced by «ZOMZ», Russia; fluorimetric determination (synthetic surface active substances (SSAS)), apparatus Fluorat-02, produced by «Lumax», Russia.

The analysis of peculiarities of the chemical composition and structure of the sample has been carried out by using the scanning electron microscope of highresolution «MIRA 3 LMU» produced by «TESCAN», Czech Republic.

\section{EXPERIMENTAL PART}

While studying and processing the carbonatation sludge, a nanocomposite carbon-baring sorbent (TMCO) has been obtained. When the carbonatation sludge is thermally treated, a combining of carbon nanoparticles with carbonate basis occurs (Fig. 1).

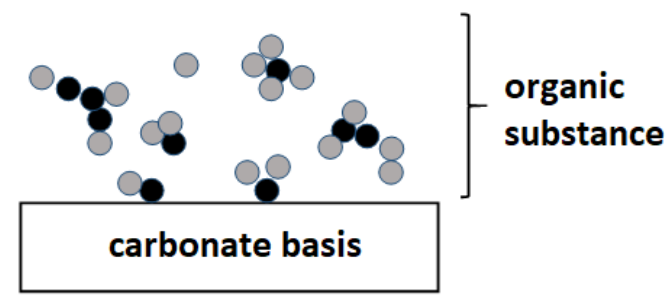

a)

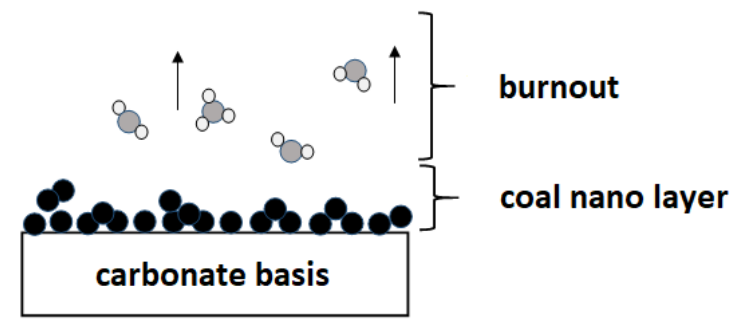

b)

Fig. 1. A combining of carbon nanoparticles with carbonate basis: a starting carbonatation sludge, $\mathrm{b}$ - after thermal treatment, where carbon, $\mathrm{O}$ - other chemical elements and radicals $\mathrm{O}$ - oxigen

Electron microscopy allows getting valuable information about the structure of the obtained material samples [1], which were thermally treated at $600^{\circ} \mathrm{C}$. Figure 2 represents a microphotograph of the starting carbonatation sludge. The particles have a lot of small round humps, but their structure is rather compact. There are cracks and hollows but their amount is small.

The nanostructure of different parts of the obtained particles of the sorption material can be seen in Figure 3. The nano layer of the amorphous carbon creates heterogeneous covering whose humps and hollows are active centers of sorption processes. The material structure is much more friable, the particle conglomerates of the starting material are formed from smaller formations, which are 300, 100 nanometers or even less in size, that indicates that significant changes take place on TMCO particle surface being thermally treated. The rounded hilly surface relief is changed with flakeand plate-like particles of the generated soot. The size of visible plates ranges from 0.1 to 0.5 micrometers or $100-150$ nanometers; the plate thickness, in all probability, does not exceed 50 nanometers. TMCO particles have a lot of voids and canals, the size of which is 50 nanometers or less.

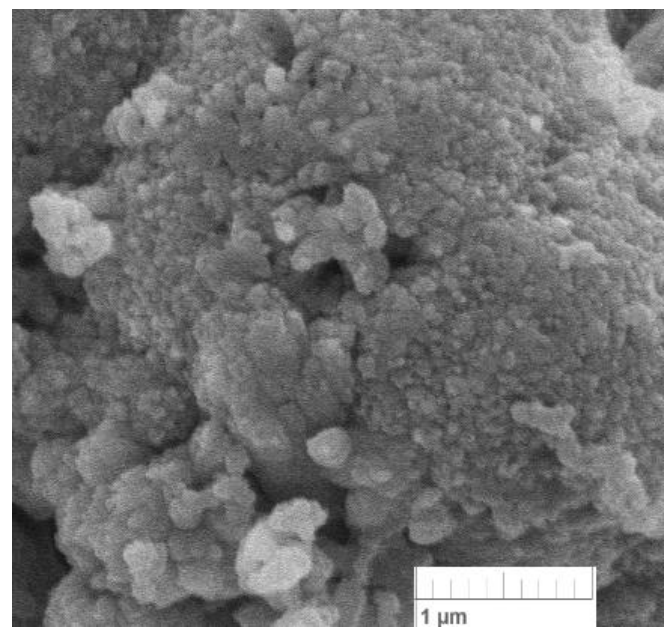

Fig. 2. The nanostructure of different parts of particles of the starting carbonatation sludge 


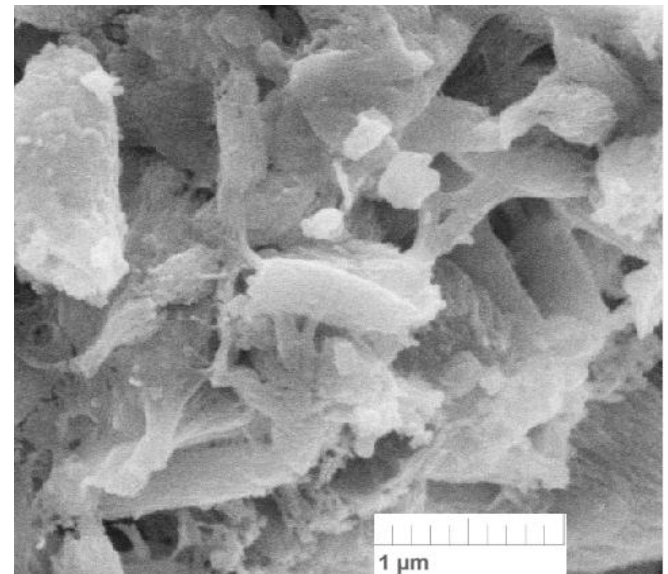

Fig. 3. The nanostructure of different parts of particles of the obtained sorption material

Figure 4 represents a differential curve of the TMCO particle diameters which confirms the nanodimensional nature of the basic mass of the material particles. Thus, as a result of thermal treatment of the starting carbonatation sludge, there is an obtained nanostructured carbon-bearing material, which due to its carbon layer covering the surface and penetrating into the particles, possesses high sorption properties. Moreover, the carbon layer formed after the thermal treatment adds TMCO some hydrophobic properties (Fig. 5).

It plays an important role when removing oil products, fat and oil contaminants, which are also hydrophobic, from aquatic environments.

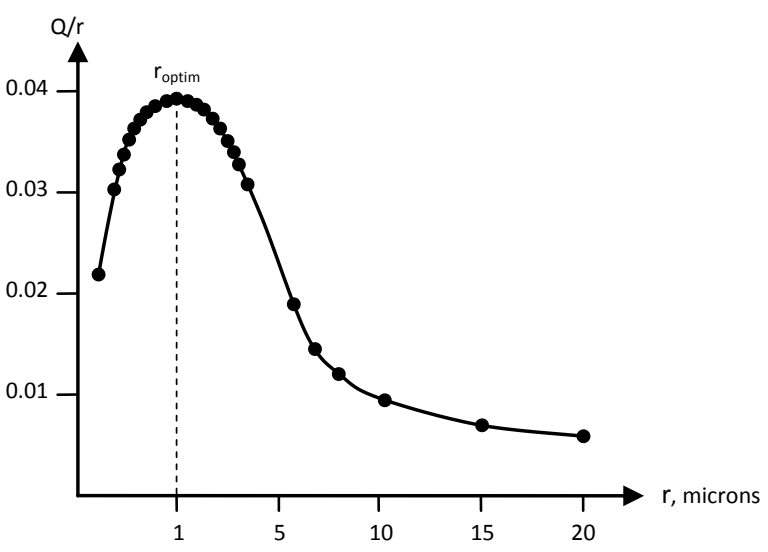

Fig. 4. A differential curve of the TMCO particle diameters

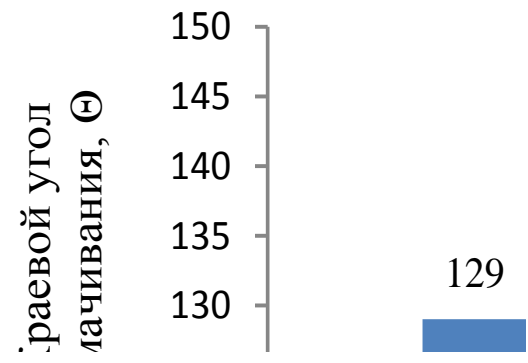

Fig. 5. Contact angles of wetting: $1-\mathrm{TMCO}, 2$-carbon from its surface
The carbon on the particle surfaces is represented in the form of amorphous long-chain structures (Figure 6).

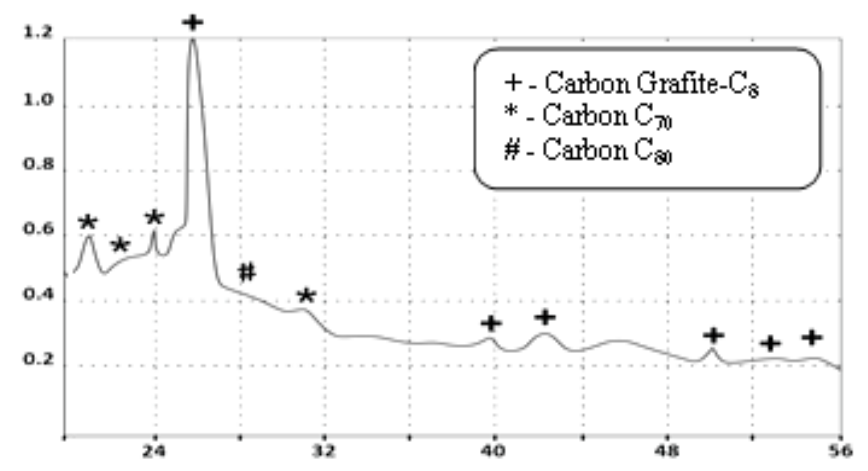

Fig. 6. A TMCO carbon roentgenogram

The generated nanocomposite material is tolerant of alkaline and neutral conditions. Under acidic condition the carbonate matrix neutralizes acids contained in wastewaters and standard test solutions, and nanoparticles with contaminants form aggregates precipitated.

The generated nano layer has a high sorption activity with respect to a wide range of contaminants. The interactions between sorption materials and oil products, wastewater components of dairy milk processing industry, copper and nickel ions, sodium lauryl sulfate, orange $\mathrm{R}$ and methylene blue dyes have been studied. Some part of the obtained results is represented in Figure 7.

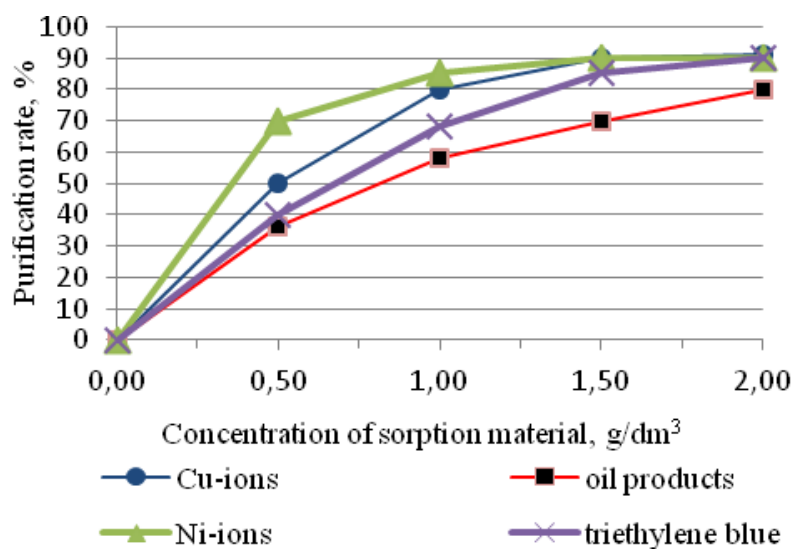

Fig. 7. Sorption activity with respect to different contaminants

Figure 8 represents a microphotograph of the sorption interaction results between TMCO and protein-based particles removed from the test wastewater containing milk components. 


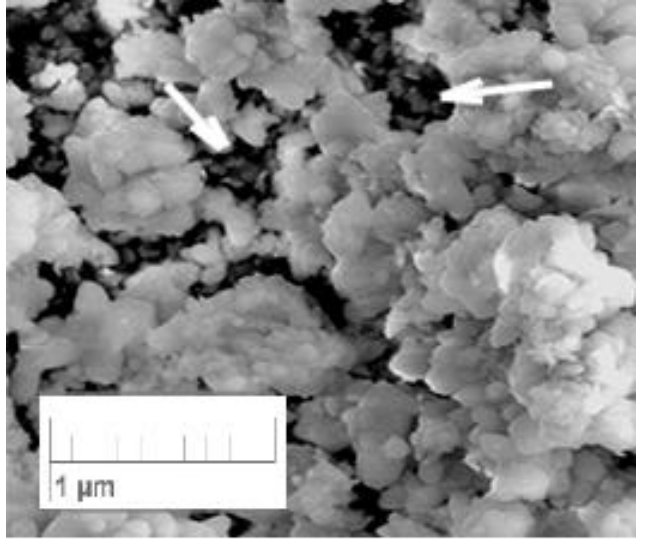

Fig. 8. A microphotograph of TMCO with protein-based particles where sorption material parts are indicated with arrows

For oily emulsions a sufficient quantity of added sorption material is $15 \mathrm{~g} / \mathrm{dm}^{3}$ when $\mathrm{COD}_{\text {start }}=340 \mathrm{mgO} / \mathrm{dm}^{3}$. For nickel- and copper-bearing solutions a sufficient concentration of nanocomposite sorbent, when purification efficiency reaches up to $98 \%$, is $2 \mathrm{~g} / \mathrm{dm}^{3}$ solution $\left(C_{\text {start }}=30 \mathrm{mg} / \mathrm{dm}^{3}\right)$. For dye solutions orange $\mathrm{R}$ with initial concentration 25 $\mathrm{mg} / \mathrm{dm}^{3}$ and methylene blue with $\mathrm{C}_{\text {start }}=30 \mathrm{mg} / \mathrm{dm}^{3}$ the maximal purification efficiency is reached when sorption material concentration is $30 \mathrm{~g} / \mathrm{dm}^{3}$ [16-18].

For the investigated materials the calculations of adsorption heat values $(\Delta \mathrm{H})$ have been done. They allowed establishing that the interaction occurs due to the complex contaminants adsorption mechanism (Van der Waals forces, hydrogen bonds, hydrophobic interaction) of wastewaters by the nanoparticles of the coal layer on the surface of the carbonate basis (Fig. 9).

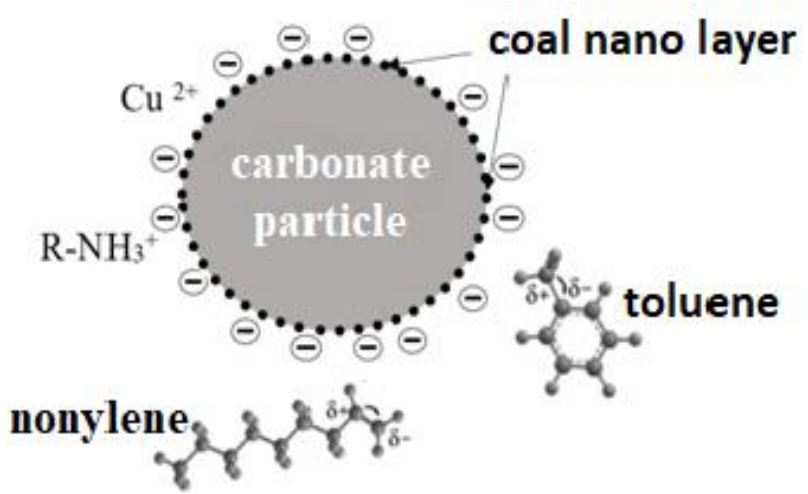

Fig. 9. A complex adsorption mechanism of contaminants

The effectiveness of adsorption properties of the material under the condition of multicomponent wastewater was confirmed by tests in industrial laboratories of different enterprises. As an example, there are research results obtained in the laboratory of the plant «Novator», Belgorod city (Table $1)$.
TABLE I. THE RESULTS OF THE EXPERIMENTS OBTAINED IN THE INDUSTRIAL LABORATORY OF THE PLANT «NOVATOR» (BELGOROD CITY)

\begin{tabular}{|c|c|c|c|c|}
\hline $3 B$ & $\begin{array}{c}\text { Additive } \\
\mathrm{TMCO}_{600} \\
\mathrm{~g} / \mathrm{dm}^{3}\end{array}$ & $\begin{array}{c}\mathrm{C}_{\text {start }}, \\
\mathrm{mg} / \mathrm{dm}^{3}\end{array}$ & $\begin{array}{c}\mathrm{C}_{\mathrm{con}}, \\
\mathrm{mg} / \mathrm{dm}^{3}\end{array}$ & $\begin{array}{c}\text { Treatment } \\
\text { efficiency, \% }\end{array}$ \\
\hline Ions $\mathrm{Ni}^{2+}$ & 0.5 & 3 & 0.003 & 99.9 \\
\hline Ions $\mathrm{Cu}^{2+}$ & 0.5 & 1 & 0.0006 & 99.9 \\
\hline COD & 0.5 & 324.2 & 99.4 & 69.3 \\
\hline $\mathrm{SO}_{4}{ }^{2-}$ & 0.5 & 427.0 & 6.58 & 98.4 \\
\hline $\mathrm{PO}_{4}{ }^{3-}$ & 0.5 & 57.3 & 3.92 & 93.1 \\
\hline Fats & 0.5 & 1.6 & 0.51 & 68.1 \\
\hline $\begin{array}{l}\text { Suspended } \\
\text { materials }\end{array}$ & 0.5 & 962.3 & 381.2 & 60.4 \\
\hline $\mathrm{OP}$ & 0.5 & 11.6 & 4.23 & 67.0 \\
\hline SSAS & 0.5 & 1.5 & 0.45 & 70.0 \\
\hline Ions $\mathrm{Ni}^{2+}$ & 1.0 & 3 & 0.002 & 99.9 \\
\hline Ions $\mathrm{Cu}^{2+}$ & 1.0 & 1 & 0.0004 & 99.9 \\
\hline COD & 1.0 & 324.2 & 98.5 & 69.6 \\
\hline $\mathrm{SO}_{4}{ }^{2-}$ & 1.0 & 427.0 & 6.21 & 98.5 \\
\hline $\mathrm{PO}_{4}{ }^{3-}$ & 1.0 & 57.3 & 3.45 & 93.9 \\
\hline Fats & 1.0 & 1.6 & 0.46 & 71.2 \\
\hline $\begin{array}{l}\text { Suspended } \\
\text { materials }\end{array}$ & 1.0 & 962.3 & 373.4 & 61.2 \\
\hline OP & 1.0 & 11.6 & 4.10 & 64.6 \\
\hline SSAS & 1.0 & 1.5 & 0.42 & 72.0 \\
\hline Ions $\mathrm{Ni}^{2+}$ & 1.5 & 3 & 0.001 & 99.9 \\
\hline Ions $\mathrm{Cu}^{2+}$ & 1.5 & 1 & 0.0003 & 99.9 \\
\hline COD & 1.5 & 324.2 & 96.40 & 70.3 \\
\hline $\mathrm{SO}_{4}{ }^{2-}$ & 1.5 & 427.0 & 5.68 & 98.7 \\
\hline $\mathrm{PO}_{4}{ }^{3-}$ & 1.5 & 57.3 & 3.20 & 94.4 \\
\hline Fats & 1.5 & 1.6 & 0.40 & 75.0 \\
\hline $\begin{array}{l}\text { Suspended } \\
\text { materials }\end{array}$ & 1.5 & 962.3 & 362.70 & 62.3 \\
\hline OP & 1.5 & 11.6 & 3.92 & 66.2 \\
\hline SSAS & 1.5 & 1.5 & 0.39 & 74.0 \\
\hline
\end{tabular}

TABLE II. THE CALCULATION RESULTS OF THE SLUDGE COMPONENTS FOR OILY WASTE, PART 1

\begin{tabular}{|c|c|c|c|c|c|}
\hline \multirow{2}{*}{ Parameter } & \multicolumn{5}{|c|}{ Component } \\
\cline { 2 - 6 } & $\mathrm{K}_{2} \mathrm{O}$ & Nitrogen & $\mathrm{OC}^{*}$ & $\mathrm{SiO}_{2}$ & $\mathrm{Ca}(\mathrm{OH})_{2}$ \\
\hline Content, \% & 0.20 & 0.10 & 0.15 & 1.20 & 1.20 \\
\hline $\mathrm{C}_{\mathrm{i}}, \mathrm{mg} / \mathrm{kg} \cdot 10^{3}$ & 2.0 & 1.0 & 1.5 & 12.00 & 12.00 \\
\hline $\begin{array}{c}\text { Background } \\
\text { concentration in } \\
\text { soil, \% }\end{array}$ & $\begin{array}{c}3.28 \\
(2.09-\end{array}$ & - & - & $\begin{array}{c}70.71 \\
(59.14-\end{array}$ & - \\
\hline $\mathrm{n}$ & - & - & - & - & 9 \\
\hline $\mathrm{X}_{\mathrm{i}}$ & 4.00 & 4.00 & 4.00 & 4.00 & 3.30 \\
\hline $\mathrm{Z}_{\mathrm{i}}$ & 5.00 & 5.00 & 5.00 & 5.00 & 4.07 \\
\hline $\begin{array}{c}\text { lgW } \mathrm{W}_{\mathrm{i}} \\
\text { Danger level } \\
\text { coefficient } \mathrm{W}_{\mathrm{i}}, \\
\mathrm{mg} / \mathrm{kg} \cdot 10^{5}\end{array}$ & 10.00 & 10.00 & 10.00 & 10.00 & 0.12 \\
\hline $\begin{array}{c}\text { Danger level } \\
\text { index } \mathrm{K}_{\mathrm{i}}\end{array}$ & 0.0020 & 0.0010 & 0.0015 & 0.0120 & 1.0238 \\
\hline
\end{tabular}

* Nitrogenous and nitrogen free organic compounds 
As it can be seen from the results represented in Table 1, the obtained nanocomposite sorption material possesses absorbing activity with respect to a wide range of contaminants of water with different chemical composition.

The slime obtained as a result of wastewater treatment has a low danger level (Tables 2, 3) and can be used without restriction for creating binding and building composite materials of different purposes.

TABLE III. THE CALCULATION RESULTS OF THE SLUDGE COMPONENTS FOR OILY WASTE, PART 2.

\begin{tabular}{|c|c|c|c|c|c|}
\hline \multirow{2}{*}{ Parameter } & \multicolumn{5}{|c|}{ Components } \\
\cline { 2 - 6 } & Soot & $\mathrm{OP}$ & $\mathrm{CaCO}_{3}$ & Water & $\mathrm{P}_{2} \mathrm{O}_{5}$ \\
\hline Content, \% & 0.25 & 0.50 & 38.00 & 58.20 & 0.20 \\
\hline $\mathrm{C}_{\mathrm{i}}, \mathrm{mg} / \mathrm{kg} \cdot 10^{3}$ & 2.5 & 5.0 & 380.0 & 582.0 & 2.0 \\
\hline $\begin{array}{c}\text { Background } \\
\text { concentration in } \\
\text { soil, \% }\end{array}$ & - & - & - & - & - \\
\hline $\mathrm{n}$ & 7 & 12 & - & - & 11 \\
\hline $\mathrm{X}_{\mathrm{i}}$ & 2.88 & 3.08 & 4.00 & 4.00 & 2.92 \\
\hline $\mathrm{Z}_{\mathrm{i}}$ & 3.50 & 3.77 & 5.00 & 5.00 & 3.56 \\
\hline $\begin{array}{c}\text { lgW } \\
\mathrm{i}\end{array}$ & 3.50 & 3.77 & 6.00 & 6.00 & 3.56 \\
\hline $\begin{array}{c}\text { Danger level } \\
\text { coefficient } \mathrm{W}_{\mathrm{i}}, \\
\mathrm{mg}_{\mathrm{kgg}} \cdot 10^{5}\end{array}$ & 0.03 & 0.06 & 10.00 & 10.00 & 0.04 \\
\hline $\begin{array}{c}\text { Danger level index } \\
\mathrm{K}_{\mathrm{i}}\end{array}$ & 0.7906 & 0.8506 & 0.3800 & 0.5820 & 0.5565 \\
\hline \multicolumn{5}{|l|}{ Index K waste danger level: 4,2000 } \\
\hline
\end{tabular}

\section{CONCLUSION}

As a result of the conducted analytical and experimental studies, the effectiveness of the thermal modification of the carbonatation sludge (TMCO) has been established. Under the effect of high temperature, a combination of carbon nanoparticles with carbonate basis occurs. According to the results of microstructural analysis, the nano layer of the amorphous carbon creates heterogeneous covering, which humps and hollows are active centers of sorption processes. As a result of TMCO concentration optimization, it is possible to reach maximal purification efficiency of wastewater with different chemical compositions. The TMCO adsorption process consists in a complex action at the expense of Van der Waals forces, hydrogen bonds, hydrophobic interactions.

\section{FINDING}

The sorption material obtained on the basis of carbonate waste of sugar industry has a developed surface structure consisting of carbon nanoparticles. It demonstrates high sorption activity with respect to a wide range of contaminants: oil products, copper and nickel ions, dyes. Its usage is perspective in respect of multicomponent wastewater of chemical, petrochemical production and other environmentally unfriendly conditions. The effectiveness of the adsorption properties of a new sorbent was confirmed under test conditions in industrial laboratories of different enterprises. TMCO is characterized by high purification efficiency that meets the requirements specifications and appears to be a competitive product among inexpensive sorbents.

\section{Acknowledgment}

The work is realized in the framework of the Program of flagship university development on the base of Belgorod State Technological University named after V.G. Shoukhov, using equipment of the High Technology Center at BSTU named after V.G. Shoukhov.

\section{References}

[1] M. Gaouar-Yadi, K. Tizaoui et al., "Efficient and eco-friendly adsorption using low-cost natural sorbents in waste water treatment", Indian Journal of Chemical Technology, vol. 23, pp. 204-209, 2016.

[2] S. E. Moradi, "Naphthalene Removal From Water by Novel Mesoporous Carbon Nitride Adsorbent", Chem. Biochem. Eng. Q., 27(3), pp. 365372, 2013.

[3] Lozano-Castello, D. Lozano-Castello, M.A. Lillo-Rodenas, "D. Preparation of activated carbons from Spanish anthracite", Carbon, vol. 39, pp. 741-749, 2001.

[4] C. Namasivayam, D. Kavitha, "Removal of Congo red from water by adsorption onto activated carbon prepared from coir pith, an agricultural solid waste", Dyes and Pigments, vol. 54 (1), pp. 47-58, 2002.

[5] Azat Seitkhan, "Synthesis of carbonized nano mesoporous sorbents based on vegetable raw materials", Nanoscience and nanoengineering, vol. 1(1), pp. 41-44, 2003

[6] K. Jusufi, Bardha Korça, Avni Berisha et al., "Potential Application of Orange Peels as Bio-Sorbents in The Removal of organic molecules from wastewater", RAD Conference Proceedings, vol. 1, pp. 176-178, 2016.

[7] A. Mendez, S. Barriga, J.M., G. Gasco, “Adsorbent materials from paper industry waste materials and their use in $\mathrm{Cu}$ (II) removal from water", Journal of Hazardous Materials, vol. 165 (1-3), pp. 735-743, 2009.

[8] S.D. Khattri, M.K. Singh, "Colour removal from dye waste-water using sugarcane dust as an absorbent", Absorption Science \& Technology, vol. 17 (4), pp. 269-282, 1999

[9] V.M. Osokin, V.A. Somin, L.F. Komarova, "Sorbents based on sunflowe husk to treat water from copper compounds", Polzunovskij vestnik, vol. 3, pp. 257-258, 2014.

[10] I.G. SHajhiev, I.SH. Abdullin, K.I. SHajhieva, "The influence of plasma treatment parameters on sorption properties of flax shive with respect to nickel ions", Vestnik Kazansk technological university, vol. 17(14), pp. $184-187,2014$.

[11] S.V. Sverguzova, ZH.A. Sapronova, "application of modified wastes of corn cobs to treat solutions from nickel ions", Ecological problems of mining regions, pp. 114-116, 11-12 September International youth conference, p. 340, 2012]

[12] N.A. Sobgajda, L.N. Olshanskaya, YU.A. Makarova, "Waste filters from wastewater treatment”, Manufacture ecology, vol. 3, pp. 68, 2012.

[13] Xiangtao Wang, Yifei Guo, Li Yang and al., "Nanomaterial as sorbents to remove heavy metal ions in wastewater treatment", Environmental \& Analytical toxicology, vol. 2 (7), 2012, p. 7

[14] J.P. Ruparelia, S.P. Duttagupta, A.K. Chatterjee, S. Mukherji, "Potentia of carbon nanomaterials for removal of heavy metals from water", Desalination, vol. 232 (1), pp. 145-156, 2008.

[15] Su F. Wu, Qing H. Li and al., "Properties of a nano CaO/Al2O3 CO2 sorbent”, Ind. Eng. Chem. Res., vol. 47(1), pp. 180-184, 2008.

[16] Zh.A.Sverguzova, D.A. Elnikov, S.V. Sverguzova, "About a possibility to use sugar industry waste for wastewater treatment", Vestnik Belgorodskog state technological university named after V.G. SHuhova, vol. 3, pp. 128-133, 2011.

[17] Zh.A. Sapronova, R.O. Fetisov, S.V. Sverguzova, "Sorption removal of lauril-sulfate sodium from aquatic environments by means of sugar 
industry waste", Vestnik Kazansk technological university, vol. 3, pp. 163-166, 2014.

[18] N.S. Lupandina, Z.A. Sapronova, S.V. Sverguzova, V.S. Lesovik, "Copper and nickel substances extraction from water medium by waste of disaccharide production", Journal of Engineering and Applied Sciences, vol. 9 (8), pp. 310-315, 2014.

[19] M.B. Kleyman, "Filtration sludge utilisation: problems and possibilities", Sugar industry, vol. 4, pp. 13-17, 1995.

[20] L.A. Vlasova, O.V. Karmanova, I.N. Matyushchenko, M.A. Gribanova, "The usage of beet sugar industry waste in rubber compound formula", Ecology and industry in Russia, vol. 10, pp. 31-33, 2014.

[21] I.N. Matyushchenko, L.A. Vlasova, "Problems of applying filtration sludge of beet sugar production", Ecology and life safety, pp. 72-75, 2007, 1-31December [VII International theoretical and practical conference, p.342, 2007] 